\title{
The Study of the Scale through Space. Teaching Innovation Experience among Architecture Schools: Malaga, Seville and Palermo ${ }^{+}$
}

\author{
Susana Garcia-Bujalance ${ }^{1}$, Manfredi Leone ${ }^{2}$ and Daniel Navas-Carrillo ${ }^{3, *}$ \\ 1 Department of Art and Architecture, University of Malaga, 29071 Malaga, Spain; sgbujalance@uma.es \\ 2 Department of Architecture, University of Palermo, 90128 Palermo, Italy; manfredi.leone@unipa.it \\ 3 Department of Urbanism and Regional Planning, University of Seville, 41012 Seville, Spain \\ * Correspondence: dnavas@us.es; Tel.: +34-627-345-041 \\ + Presented at the 2nd Innovative and Creative Education and Teaching International Conference \\ (ICETIC2018), Badajoz, Spain, 20-22 June 2018.
}

Published: 11 December 2018

\begin{abstract}
The educational innovation project object of this communication focuses on the scale problems that arise in the projects of territorial planning carried out in architecture schools, but also in the loss of the scale concept related to thought and drawing. The project involved collaboration among the Schools of Architecture of Malaga, Palermo and Seville with the aim of carrying out a practical exercise among the students of two subjects that, working on different scales, addressed similar concepts. In particular, following an PBL methodology based on collaborative projects, the planning of the N-340 road in the city of Nerja (Málaga) was carried out. Firstly, the territorial scale is addressed in the subject of Urbanism IV at the School of Architecture of Malaga, proposing the continuity of its development at the scale of landscape design in another place and with other designers of the course of Landscape Laboratory at the School of Architecture of Palermo. Besides, having verified that the academic results have been -in general terms- more satisfactory, the project has allowed consolidating the academic relationship between the three schools, which has translated into the development of complementary training actions.
\end{abstract}

Keywords: active learning; collaborative project-based learning; educational innovation project; landscape; problem-based learning (PBL); teaching methods; territorial planning; urbanism; tourism

\section{Introduction}

There has not been such a powerful tool that profoundly modifies the conception of architecture, and consequently its teaching, such as computer-aided design. This tool of drawing and spatial representation incorporates a new conception of the graphic scale. One of the architecture student requirements is to manage the graphic scales, not only as a mean of representation but also as an adapting instrument to different levels of approach to the reality. The exercise of drawing the territory on a scale of 1:50,000, a city on a scale of 1:2000, a building on a scale of 1:100, or a constructive detail on a scale of 1:10, deepens the need to think about what it means to work on each of these scales. This implies being able to ignore those elements that are not relevant to that scale of thought, to focus on what is truly determining when it comes to projecting a territory, a city, a building or a constructive detail. This ability distinguishes architecture from other disciplines, such as habitual collaborators who focus on more specific scales. Only architecture transits in a constant way between the territorial scale and the constructive detail. And this transit is learned by drawing at different scales. Since drawing is thinking. 
However, the computer-aided drawing allows drawing at a scale of 1:1, since the "zoom" brings the drawing closer to any scale of detail, even if it is millimetric. This possibility, which may seem initially positive can lead to a loss of the sense of scale when thinking on different scales has not been learned. Many older professionals, who have learned to draw on paper, have found in CAD system a great help to accurately develop their projects. The problem arises when students directly learn to draw using computer-aided design. This problem is shown with greater incidence in the courses of urbanism, as students have to make decisions that affect buildings inserted in a certain territorial space (1:500 to 1:100) but to work at scales of representation (1:50,000 to 1:2000). This generates a great confusion among the students who have to deal with these scales for the first time.

In 2015, we requested financial support to develop an Educational Innovation Project to work on overcoming this issue: "The design of public space as a landscape strategy in the sustainable management of the tourist territory. A joint experience between the University of Palermo and the International Campus of Excellence Andalucia Tech: Malaga-Seville". The aim was to highlight the problems of scale in territorial planning projects, working on a relevant tourist area such as Nerja in Malaga and allowing students in two different subjects, related in their causes and effects, to understand the meaning of scaling up their thinking through representation. Hence, we design an exercise following a PBL methodology [1] based on collaborative projects [2] to be jointly developed between Urbanism IV at the School of Architecture of Malaga (Spain) and Landscape Laboratory at the School of Architecture of Palermo (Italy).

\section{Materials and Methods}

The Educational Innovation Project was carried out between 2015 and 2017. Specifically, the practical implementation was initiated in the second semester of the 2015-2016 academic year by the students of Urbanism IV. This subject works on planning a great linear axis that articulates different territorial realities: The N-340 road in the city of Nerja (Málaga) [3]. This axis connects the historic centre with peri-urban areas such as tourist areas, industrial environments or agricultural areas. Working on an element such as this axis implies a territorial analysis that is not only limited to itself but also requires thinking about all the elements that affect and condition it. Thus, students from natural critical thinking [4] had to address the N-340 from a territorial approach $(1: 100,000)$, but without ignoring the constructed reality and the spatial articulation among architectural typologies, urban facilities or open areas (1:100). The exercise was to be concluded with a series of strategic proposals to be represented on a scale appropriate to each project. These can range from 1:10,000 scale to 1:100 scale. Even the definition of standard construction details may require a 1:20 scale.

Trying to define every detail is the main problem that students had. One of the methodological strategies was to approach the exercise as if it were the programme for an architectural competition. The aim was to make them understand that, although there are elements that have to be deeply defined to act effectively in the territory, there were others must be developed later by others. Their proposals should define what cannot be interpreted but leave open those aspects that have to do with the creative capacity of other designers. This mental exercise allowed them to develop their strategic proposals knowing that they would be concrete into specific actions by the students of Palermo.

The project was continued in the second semester of the 2016-2017 academic year by the students of the Landscape Laboratory. They must develop a complete design of an urban or peri-urban public space between 500 and $5000 \mathrm{~m}^{2}$ [5]. In these exercises, they must design all the elements of a public space. Although students are able to understand the working scale of this exercise, they lack an approximation to the territorial logic of these spaces. However, when these public spaces are located in peripheral areas, understanding their territorial and urban functions is essential in order to decide how to undertake the exercise. We cannot ignore the fact that human activity in the 21st century is not limited to a specific space such as the historic city, but that the urban experience has become a territorial experience. We work, live, consume leisure and interact with others in different places. This new condition of urbanity demands that we train our students in the understanding of territory and its link with the scale that directly affects us: the immediate and most sensitive. 
To facilitate interactivity among participants from both universities, a website was designed. The exercises of the students from Malaga were posted to be consulted by their Italian colleagues. In addition, a virtual conference was also held to explain and clarify the strategic proposals developed in Urbanism IV to the students from Palermo. Therefore, this project could be a good scalar learning experience for the students of Landscape Laboratory, while for the students of Urbanism IV it would be very useful to see how their strategic proposals would have continuity in projects developed by other colleagues. In fact, this is something that regularly happens in the exercise of the profession.

Once the Landscape Laboratory course was completed, an exhibition with the public space final designs was organised at the School of Architecture in Malaga. In addition, Manfredi Leone, coordinator of the Landscape Laboratory, gave a lecture in Malaga and another at the School of Architecture in Seville. Thus, the students of Urbanism IV would finally understand the strategic dimension of their project through the design that the Italian students had made from their proposals.

As a final phase of the project, and trying to evaluate the result of the experience, several lectures and researchers from Malaga, Seville and Palermo analysed the students' work from a double perspective: from the representation of the territory and its problems, as well as, from the disciplinary and professional compared vision of urban planning in Italy and Spain.

\section{Results and Discussion}

One of the most important contributions to this project has been a two-way path, MalagaPalermo-Malaga, from an active learning methodology [6] that has sought to place the student at the centre of learning [7]. From an attitudinal point of view, the exercise also sought to highlight the points of union between two distant territories, but with a large number of cultural and landscape coincidences, which made it possible to understand the territory where the students of Landscape Laboratory had to work, even without physically visiting it.

Certainly, the Urbanism IV course was not the most suitable for the experience because the students were not sufficiently motivated or did not understand entirely its purpose. This fact meant that the interaction among the students of both universities was not achieved. It is also noteworthy that only three of the eighteen groups actively participated in the exhibition organized in Nerja, which purpose was to involve citizens and their political representatives in the strategies of this academic exercise through an open discussion with them [8]. It should also be noted that both subjects were taught in different academic years, which had a particular impact on the participation of students from both groups. On the one hand, during the development of Urbanism IV the students of Landscape Laboratory, who would have to continue with the exercise, had not yet enrolled. The possibility of contacting their Italian colleagues would have been an incentive to increase the degree of involvement of the students of Urbanism IV. On the other hand, although the group from Palermo was quite active, there was no response from Spanish students, who were not interested in the project once they had passed the course. The raised doubts had to be directly solved by the lecturer and coordinator of Urbanism IV.

The experience was of great interest to the participating teaching staff based on the academic results achieved, especially in the case of Landscape Laboratory, and the consolidation of the academic relationship among the Schools of Architecture of Malaga, Palermo and Seville. This has been translated into complementary training activities, such as the aforementioned conferences and exhibitions, but also into actions that go beyond the project's purpose. Specifically, a particular interest arose in relation to the teaching of landscape, which was the main topic in common of the two subjects that participated in the Educational Innovation Project. The landscape is a concept yet to be defined that allows many different approaches and one of the keys to the exercise carried out. Thus, the teaching staff of Seville, Malaga and Palermo agreed to edit a book about teaching methodologies related to the landscape and the territorial planning. Other Mediterranean schools of architecture, both Spanish and Italian, also participated in this publication. The result was the book entitled "Territory, Landscape and Tourism: Teaching Methodologies in Schools of Architecture" [9], which has been extremely well received by the teaching staff of the different participating schools. 


\section{Conclusions}

This experience has shown that the teaching of scales in architecture requires innovative approaches in pedagogy, rather than in technique since it is precisely this that is generating the problem. For this reason, it is necessary to establish contact mechanisms with the professional reality which, in the case of architecture, involves imagining that there will be other professionals who will have to continue the work that a team of architects can carry out at any given time. Therefore, doing shared exercises at the scale between different subjects can be an effective way of training students in professional skills, the ultimate goal of higher education [10]. Experiences between two different universities like this are not a must. However, it is quite useful to disassociate students from their own academic context collaborating with unknown persons. This is a common practice in the exercise of the profession. A less static group and the coordination of actions in the same academic year would have helped to obtain satisfactory results.

However, the experience, in addition to being useful in bringing together professors from different architecture schools in common researching themes, has also helped two students from Palermo, who have been clearly more active than those from Urbanism IV, to choose Malaga to carry out their final project degree. This has meant that these two students have had mobility stays at the University of Malaga to develop detailed fieldworks. This has meant that these two students have had mobility stays at the University of Malaga to develop detailed fieldworks.

Acknowledgments: The authors are grateful for the financial support from the University of Malaga and the involvement of the students and the rest of the teaching staff who have participated in the project.

\section{References}

1. Servicio de Innovación Educativa, Aprendizaje Basado en Problemas; Universidad Politécnica de Madrid: Madrid, Spain, 2008.

2. Fernando Herrera, R. Aprendizaje basado en proyectos colaborativos de entornos de programación a partir de proyectos de ingeniería civil. Revista Electrónica Educare 2017, 21, 1-18, doi:10.15359/ree.21-2.10.

3. Bain, K. What the Best College Teachers Do, 1st ed.; Harvard University Press: Cambridge, MA, USA, 2004.

4. Urbanismo IV. Programación Docente de la Asignatura. Grado en Arquitectura. Escuela Técnica Superior de Arquitectura. Universidad de Malaga. Curso 2015-2016. Available online: https://oas.sci.uma.es:8443/ht/ 2015/ProgramasAsignaturas_Titulacion_5016_AsigUMA_52319.pdf (accessed on 28 May 2018).

5. Laboratorio di Arte dei Giardini ed Architettura del Paesaggio. Materiale e Informazioni Relativi All'insegnamento. Corso di Studi Architettura. Università Degli Studi di Palermo. Anno Accademico 20162017. Available online: https://www.unipa.it/persone/docenti/a/marcella.aprile/?pagina=insegnamento\& idInsegnamento=68387\&idCattedra $=44012$ (accessed on 28 May 2018).

6. Santos Asensi, C.; Palacios Vicario, B. Metodologías activas en el espacio superior de enseñanza. In Contribuyendo a una Nueva Docencia a Partir del EEES; Peña Acuña, B., Ed.; Tecnos: Madrid, Spain, 2017; pp. 453-467.

7. Finkel, D. Teaching with Your Mouth Shut; Butterworth Heinemann: Oxford, UK, 2000.

8. García Bujalance, S. La articulación del Territorio: La N-340 a su paso por Nerja. Catálogo de la Exposición de los Trabajos del Alumnado de Urbanismo IV, de la Escuela de Arquitectura de Málaga, Expuesta en la Sala Mercado del Ayuntamiento de Nerja, 1st ed.; Servicio de Publicaciones y Divulgación Científica de la Universidad de Málaga: Málaga, Spain, 2016.

9. García Bujalance, S.; Leone, M. (Eds.) Territorio, Paisaje y Turismo: Metodologías Docentes en las Escuelas de Arquitectura, 1st ed.; Geometría. Seminario de difusión de la arquitectura: Malaga, Spain, 2017.

10. García Manjón, J.V.; Pérez López, M.C. Espacio Europeo de Educación Superior. Competencias Profesionales y Empleabilidad. Rev. Iberoam. Educ. 2008, 46, 1-12. Available online: https://rieoei.org/RIE/article/view/1886 (accessed on 28 May 2018). 